\title{
Density dependence in marine protected populations: a review
}

\author{
J.L. SÁNCHEZ LIZASO*1, R. GOÑI², O. REÑONES², J.A. GARCÍA CHARTON², R. GALZIN \\ J.T. BAYLE ${ }^{1}$, P. SÁNCHEZ JEREZ ${ }^{1}$, A. PÉREZ RUZAFA ${ }^{3}$ AND A.A. RAMOS ${ }^{1}$ \\ ${ }^{1}$ Departamento de Ciencias Ambientales, Universidad de Alicante, PO Box 99, 03080 Alicante, Spain, ${ }^{2}$ IEO-Centro Oceanográfico de Baleares, PO \\ Box 291, 07080 Palma de Mallorca, Spain, ${ }^{3}$ Departamento de Ecología, Universidad de Murcia, Campus Espinardo, 30100 Murcia, Spain and \\ ${ }^{4}$ EPHE-URA CNRS 1453, Université de Perpignan, 66860 Perpignan Cedex, France
}

Date submitted: 30 June 1999 Date accepted: 18 February 2000

\section{Summary}

The cessation or reduction of fishing in marine protected areas (MPAs) should promote an increase in abundance and mean size and age of previously exploited populations. Thus density-dependent changes in life-history characteristics should occur when populations are allowed to recover in MPAs. In this review, we synthesize the existing information on resource limitation in marine ecosystems, densitydependent changes in life-history traits of exploited populations and evidence for biomass export from MPAs. Most evidence for compensatory changes in biological variables has been derived from observations on populations depleted by high fishing mortality or on strong year classes, but these changes are more evident in juveniles than in adults and in freshwater rather than in marine systems. It is unclear if adults of exploited marine populations are resource limited. This may suggest that exploited populations are controlled mainly by density-independent processes, which could be a consequence of the depleted state of most exploited populations. MPAs could be a useful tool for testing these hypotheses. If we assume that resources become limiting inside MPAs, it is plausible that, if suitable habitats exist, mobile species will search for resources outside of the MPAs, leading to export of biomass to areas which are fished. However, it is not possible to establish from the available data whether this export will be a response to resource limitation inside the MPAs, the result of random movements across MPA boundaries or both. We discuss the implications of this process for the use of MPAs as fisheries management tools.

Keymords: marine reserves, carrying capacity, density, fishery enhancement, Mediterranean, spillover

\section{Introduction}

A large number of marine protected areas (MPAs) have been established around the world during the last century (Jones et al. 1993) and while some offer protection to pristine natural

* Correspondence: Dr José Luis Sánchez Lizaso Tel: +34965903668 Fax: +34965903464 e-mail: lizaso@carn.ua.es communities, others attempt to halt further deterioration of sensitive habitats or serve as fisheries management tools for long-term sustainability of fisheries (Ramos \& McNeill 1984; Rowley 1994; Kelleher et al. 1995).

Fishing reduces population abundance, preferentially removing larger and older fish, thus changing the size and age structure of exploited populations (Jennings \& Polunin 1996; Goñi 1998). The cessation or reduction of fishing may promote an increase of abundance as well as the mean size and age of the protected populations. The effect of fishing restrictions on density and biomass of fish populations has been thoroughly investigated both in the Mediterranean (Table 1), and in other marine regions (Dugan \& Davies 1993; Jones et al. 1993; Ferreira \& Russ 1995; Jennings et al. 1995; McClanahan \& Kaunda-Arara 1996; Russ \& Alcala 1996). Most studies show that the species more likely to respond to the cessation of fishing in MPAs ('reserve effect') are large, long-lived predators, organisms highly vulnerable to fishing and those the populations of which are overexploited (PDT [Plan Development Team] 1990; Roberts \& Polunin 1993; Bohnsack 1996; Table 1). Other species may not be influenced by protection or may show the opposite response (lower abundance or biomass in MPAs), presumably due to inter-specific interactions (Table 1; Pinnegar et al. 2000).

The expected higher densities of previously-exploited species in MPAs may produce an augmentation of intraspecific and interspecific competition as biomass of the populations approaches the carrying capacity of the area. The importance of taking proper account of density-dependent changes in life-history traits for stock assessment purposes was pointed out early on by Beverton and Holt (1957). It was warned that 'the dependence of the biological parameters on population density is of fundamental importance and that failure to take this into account would probably result in overestimating the potential increases in yield that could be obtained from reducing fishing mortality' (Beverton \& Holt 1957). A number of authors have later found support for this contention (Polovina 1989; Trippel et al. 1997). In the particular context of MPAs, Hastings and Botsford (1999) emphasize the importance of density-dependent processes in their function and effectiveness as fisheries management tools.

Density-dependent compensatory processes have been proposed in numerous studies as the operating mechanisms 
Table 1 Summary of results of main studies evaluating changes $(-=$ no data) in abundance and size of fish and invertebrate species in Mediterranean MPAs relative to unprotected areas.

\begin{tabular}{|c|c|c|c|c|c|c|c|}
\hline $\begin{array}{l}\text { Country/ } \\
\text { МРA }\end{array}$ & Reference & Habitat & Methodology & $\begin{array}{l}\text { Sampling } \\
\text { design }\end{array}$ & Species/Groups & Abundance & Size \\
\hline \multicolumn{8}{|l|}{ France } \\
\hline \multirow[t]{17}{*}{ Cerbère-Banyuls } & \multirow[t]{5}{*}{ Bell 1983} & \multirow{5}{*}{$\begin{array}{l}\text { Rocky bottoms } \\
(7-20 \mathrm{~m})\end{array}$} & \multirow{5}{*}{$\begin{array}{l}\text { Visual counts } \\
\text { ANOVA }\end{array}$} & \multirow[t]{5}{*}{ Spatial } & Vulnerable species & Increase & Increase \\
\hline & & & & & Boop boops & Increase & Increase \\
\hline & & & & & Spicara chryselis & Increase & Increase \\
\hline & & & & & Chromis chromis & Increase & Increase \\
\hline & & & & & Serranus cabrilla & Decrease & Increase \\
\hline & Binche 1985 & Rocky bottoms & $\begin{array}{l}\text { Visual counts, } \\
\text { no test }\end{array}$ & Temporal & $\begin{array}{l}\text { Sparids, labrids, } \\
\text { serranids }\end{array}$ & Increase & Large-medium increased \\
\hline & \multirow{7}{*}{$\begin{array}{l}\text { Dufour et al. } \\
1995\end{array}$} & \multirow[t]{7}{*}{ Rocky bottoms } & \multirow{7}{*}{$\begin{array}{l}\text { Visual counts } \\
\text { Mann-Whitney U }\end{array}$} & \multirow{7}{*}{$\begin{array}{l}\text { Spatial and } \\
\text { temporal }\end{array}$} & Diplodus vulgaris & Increase & Large size dominant \\
\hline & & & & & Spondyliosoma cantharus & Increase & Large size dominant \\
\hline & & & & & Labrus merula & Increase & Large size dominant \\
\hline & & & & & Diplodus sargus & Decrease & - \\
\hline & & & & & Oblada melanura & Decrease & - \\
\hline & & & & & Symphodus tinca & Decrease & - \\
\hline & & & & & Mullus surmuletus & Decrease & - \\
\hline & \multirow[t]{4}{*}{ Jouvenel 1997} & \multirow{4}{*}{$\begin{array}{l}\text { Rocky bottoms } \\
(5-12 \mathrm{~m})\end{array}$} & \multirow{4}{*}{$\begin{array}{l}\text { Visual counts } \\
\text { Mann-Whitney U }\end{array}$} & \multirow{4}{*}{$\begin{array}{l}\text { Spatial and } \\
\text { temporal }\end{array}$} & Diplodus vulgaris & Decrease & Increase \\
\hline & & & & & Symphodus tinca & Decrease & Increase \\
\hline & & & & & Labrus bimaculatus & Increase & Increase \\
\hline & & & & & L. merula & Increase & Increase \\
\hline \multirow[t]{11}{*}{ Scandola } & \multirow[t]{6}{*}{ Francour 1991} & Posidonia and & Visual counts & Spatial & Dentex dentex & Increase & Large size dominant \\
\hline & & rocky bottoms & $\mathrm{X}^{2}$ test & & Diplodus sargus & Increase & Large size dominant \\
\hline & & & & & D. puntazzo & Increase & Large size dominant \\
\hline & & & & & Sarpa salpa & Increase & Large size dominant \\
\hline & & & & & Dicentrarchus labrax & Increase & Large size dominant \\
\hline & & & & & Sciaena umbra & Increase & Large size dominant \\
\hline & Francour 1994 & Posidonia and & Visual counts & Spatial and & Dicentrarchus labrax & Increase & Large size \\
\hline & & rocky bottoms & Kruskal-Wallis test & temporal & Sparus aurata & Increase & Large size \\
\hline & & & & & Epinephelus marginatus & Increase & Large size \\
\hline & & & & & Sciaena umbra & Increase & Large size \\
\hline & & & & & Posidonia fish assemblage & No change & - \\
\hline Carry-le-Rouet & Harmelin et al. & Posidonia and & Visual counts & Spatial & Mesocarnivores & Increase & Large size dominant \\
\hline & 1995 & rocky bottoms & t-test & & Diplodus spp. & Increase & Large size dominant \\
\hline & & & & & Serranus cabrilla & Increase & Large size dominant \\
\hline & & & & & Coris julis & Increase & Large size dominant \\
\hline & & & & & Symphodus spp. & Decrease & - \\
\hline Spain & & & & & & & \\
\hline Medes Islands & García-Rubies \& & Rocky bottoms & Visual counts & Spatial & Epinephelus marginatus & Increase & Large individuals \\
\hline & Zabala 1990 & & ANOVA & & Sciaena umbra & Increase & Large individuals \\
\hline & & & & & Sparus aurata & Increase & Large individuals \\
\hline & & & & & Diplodus cervinus & Increase & Large individuals \\
\hline & & & & & Dicentrarchus labrax & Increase & Large individuals \\
\hline & & & & & Mullus surmuletus & Decrease & - \\
\hline & & & & & Serranus cabrilla & Decrease & - \\
\hline Tabarca & Bayle \& Ramos & Rocky bottoms & Visual counts & Spatial & Epinephelus spp. & Increase & Increased size \\
\hline & 1993 & & Kruskal-Wallis test & & Sciaena umbra & Increase & Increased size \\
\hline & & & & Temporal & Overall assemblage & No change & - \\
\hline & Bayle 1999 & Rocky bottoms & Visual counts & Assymetrical & Epinephelus spp. & Increase & Mean size increased \\
\hline & & and Posidonia & ANOVA & design, temporal & Labrus merula & Increase & Mean size increased \\
\hline & & & & and spatial & Diplodus spp. & Increase & Mean size increased \\
\hline Campello & $\begin{array}{l}\text { Martínez } \\
\text { Hernández } 1996\end{array}$ & Posidonia & $\begin{array}{l}\text { Experimental gill } \\
\text { nets } \\
\text { ANOVA }\end{array}$ & $\begin{array}{l}\text { Spatial and } \\
\text { temporal }\end{array}$ & Mullus surmuletus & Increase & - \\
\hline Cabrera & $\begin{array}{l}\text { Reñones et al. } \\
1998\end{array}$ & $\begin{array}{l}\text { Rocky bottoms } \\
(5-10 \mathrm{~m}) \\
(20-25 \mathrm{~m})\end{array}$ & $\begin{array}{l}\text { Visual counts } \\
\text { ANOVA }\end{array}$ & $\begin{array}{l}\text { Assymetrical } \\
\text { design, temporal } \\
\text { and spatial }\end{array}$ & Epinephelus marginatus & Increase & Increase \\
\hline Columbretes & Goñi et al. 1999 & Rocky bottoms & $\begin{array}{l}\text { Experimental traps } \\
\text { ANOVA }\end{array}$ & $\begin{array}{l}\text { Assymetrical } \\
\text { design, temporal } \\
\text { and spatial }\end{array}$ & Palinurus elephas & Increase & - \\
\hline Italy & & & & & & & \\
\hline Castellammare & Pipitone et al. & Soft bottoms & Trawling & Temporal & Merluccius merluccius & Increase & - \\
\hline & 1996 & $(0-200 \mathrm{~m})$ & Mann-Whitney U & & Mullus barbatus & Increase & - \\
\hline & & & & & Pagellus erythrinus & Increase & - \\
\hline & & & & & Octopus vulgaris & Increase & - \\
\hline & & & & & Illex coindetii & Decrease & - \\
\hline
\end{tabular}


that could explain the resilience observed in exploited populations. Life-history parameters such as life-span, growth, natural mortality, age and size at maturity and reproductive patterns are thought of as plastic or adaptive (Stearns \& Crandall 1984), and could conceivably be easily affected by changes in population density in protected areas after fishing restrictions are put in place if resources become limiting. Few studies address density-dependent responses in the context of protected populations (Buxton 1993; Ferreira \& Russ 1995; Macpherson et al. 1997; Pastoors et al. 1998). In principle, compensatory changes in life-history parameters opposite to those ones described in exploited stocks should be expected when populations are allowed to recover in MPAs. Finally, since protected areas are not closed systems, the limitation of resources brought about by increased competition in dense protected populations could induce density-dependent emigration from MPAs, a process referred to as spillover. This later process would lead to a reduction of the rate of increase in density inside the protected area.

In this review we summarize the results of studies which assess potential density-dependent responses in exploited and natural marine populations. Interspecific interactions are not explicitly addressed here (Pinnegar et al. 2000). This review is divided in four sections. The first addresses resource limitation in marine populations. In the second, we review available data on density-dependent changes in lifehistory traits. The third section summarizes the available evidence on spillover from MPAs, and in the final section, the findings and implications for MPA managers are discussed.

\section{Are exploited marine populations resource limited?}

The necessary condition for competition to occur is that resources must be in short supply (Pianka 1981). In the marine environment, the resources subject to limitation are primarily food and space. Therefore, it is relevant to ask if marine ecosystems are close to their carrying capacity. Christensen and Pauly (1998) provide a functional definition of carrying capacity as 'the upper limit of biomass that can be supported by a set primary production and within a variable food web structure is reached when total system respiration equals the sum of primary production and detritus import'. Direct estimation of the carrying capacity is difficult to obtain because of the difficulties in quantifying the availability and quality of the enormous variety of foods and habitats required by all the species in a system.

An alternative for exploring the occurrence of food limitation is to look at the accuracy of inferred predictions (Edgar 1993). For instance, the observed ecosystem shifts following protection, such as cascade effects on urchins and algae (McClanahan 1994a; Sala et al. 1998), could be used as evidence of intense predation by fish, and, consequently, that food limitation is likely to occur. Caution must be exercised, however, because cascade effects may not be as widespread as previously thought (Menge 1992; Pinnegar et al. 2000), and also the effects of fish predation seem to be dependent on the scale of observation. In this regard, while several small-scale studies effectively found predation effects (Hixon \& Beets 1993), other studies at large spatial scales have failed to detect significant large-scale increases in prey abundance following decreases in predator biomass due to fishing (Bohnsack 1982; Jennings et al. 1995; Jennings \& Polunin 1997). Another signal of food limitation can be obtained by observing the proportion of time spent feeding by an individual, high foraging effort being indicative of food limitation (Bruggemann et al. 1994). Moreover, comparisons amongst sites that differ in their productivity can give some indication of the 'saturation' of habitats in terms of biomass or abundance. A comparison of total fish biomass in the Western Mediterranean MPAs of Columbretes and Cabrera showed differences which could be partially explained by their distinct levels of primary productivity under the hypothesis that fishes inside MPAs maximize the use of feeding resources (García Charton, Sánchez Jerez \& Reñones, unpublished data 1996). Hypotheses about food limitation that may be empirically corroborated in the field can be generated through model simulations of ecosystem functioning (McClanahan 1994b; Larkin 1996). For instance, mass balance trophic models such as ECOPATH (Christensen \& Pauly 1992, 1998; Arias-González et al. 1997; Arias-González 1998) allow questions such as 'what if the biomass of top predators in representative marine systems were much greater in MPAs than presently observed?' to be addressed. Predictions can thus be made about the capability of a given coastal ecosystem to sustain more biomass (Christensen \& Pauly 1998).

Habitat structure often explains a substantial proportion of the observed variation in abundance of fish species (Ault \& Johnson 1998; Friedlander \& Parrish 1998; García Charton \& Pérez Ruzafa 1998). However, direct empirical evidence that habitats are 'saturated' (i.e. reaching their carrying capacities) is difficult to obtain. In this sense, the observed response of fish assemblages to spatial variation of habitat complexity (sensu García Charton \& Pérez Ruzafa 1998) is a necessary but not sufficient condition for space limitation to be demonstrated. Therefore, much more research effort needs to be directed to studies of both food shortage and habitat limitation. Habitat limitation at the settlement and pre-recruit stages is to be expected at high densities in reef fish (Hixon \& Carr 1997) and structure-dwelling invertebrates (Caddy 1986; Wahle \& Steneck 1991) but perhaps not in macroinvertebrates in open sand (Hastings \& Botsford 1999). The recruitment limitation hypothesis, in contrast, argues that resources on reefs are rarely limiting due to the high mortality rates of eggs and larvae in the pelagic environment and, as a consequence, there are never enough recruits to saturate the reef environment (Victor 1986; Planes et al. 2000).

Density-dependent variations in life-history traits (see below) are indicative that resources may be in short supply. 
For some stocks it appears that resources can be limiting for juveniles, and to a lesser extent for adults, but this limitation is not obvious in all stocks. Although resource limitation may not operate strongly for adults in present-day exploited stocks, the possibility that resource limitation of adults could be important in unexploited populations cannot be ruled out (Jones 1989). MPAs could be useful tools for testing these hypotheses.

\section{Changes in the species life-history traits of growth rate, natural mortality rate and reproductive patterns}

\section{Gromth rates}

Growth rates of marine species show considerable plasticity in response to fluctuating availability of critical resources such as of food and shelter, population density, environmental factors and social interactions (Wootton 1990). If resources are limiting in exploited populations, fishing would lead to reduced population size and, as a result, to increased resource availability and increased growth rates. The reverse should hold true and a primary response of marine populations to increased density should be a reduction in individual growth rate and, as a consequence, a decline in the mean size-at-age of the population. At high population densities, growth rate reductions may also occur by social interaction, whether food is limiting or not. This would occur through increased competition which affects the rate of food consumption or the rate of energy expenditure (Doherty 1983; Jones 1987a; Forrester 1990; Booth 1995). This competitive interaction could be both between and within species, and could occur amongst and within cohorts depending on the overlap in resource use.

By the number of studies available, density dependence of growth rates is the best established of the density-dependent responses in marine species. In general, juveniles seem to exhibit clearer density-dependent responses than adults (Valiela 1984; Daan et al. 1990; Cushing 1995). Evidence of compensatory density-dependent processes through increased growth rates at low densities is abundant in exploited populations of distantly related species (Table 2). Reduced growth rates at high densities have been reported for juvenile and adult phases of exploited populations in the case of strong year classes (Bannister 1978; Jones 1983; Rijnsdorp \& van Leeuwen 1992, 1996), during periods of reduced fishing mortality (Beverton \& Holt 1957; Rijnsdorp \& van Leeuwen 1992) and also from the comparison of areas with different population densities (Pollock 1991b, 1997). Manipulative experiments with coral reef fish (mainly Pomacentridae and Labridae species) also provide evidence that juvenile growth is inversely related to population density (Doherty 1983; Jones 1987a; Forrester 1990; Booth 1995).

Table 2 Results of selected studies reporting changes $(-=$ no data $)$ in growth rates and reproductive traits associated with reduced population density.

\begin{tabular}{|c|c|c|c|c|c|c|}
\hline Species & Location & $\begin{array}{l}\text { Growth } \\
\text { rate }\end{array}$ & $\begin{array}{l}\text { Age at } \\
\text { maturity }\end{array}$ & $\begin{array}{l}\text { Size at } \\
\text { maturity }\end{array}$ & $\begin{array}{l}\text { Sex } \\
\text { change }\end{array}$ & Reference \\
\hline \multicolumn{7}{|l|}{ DEMERSAL FISH } \\
\hline \multirow[t]{2}{*}{ Merluccius bilinearis } & N Georges Bank & No change & Decreased & - & - & Helser \& Almeida 1997 \\
\hline & S Georges Bank & Increased & Decreased & - & - & Helser \& Almeida 1997 \\
\hline \multirow[t]{2}{*}{ Gadus morhua } & NE Atlantic & Increased & Decreased & - & - & Jorgensen 1990 \\
\hline & NW Atlantic & - & Decreased & Decreased & - & $\begin{array}{l}\text { Saborido-Rey \& Junquera } \\
1998\end{array}$ \\
\hline Lepidorhombus boscii & NE Atlantic & Increased (juveniles) & - & - & - & Landa 1999 \\
\hline Hippoglossoides platessoides & NW Atlantic & Increased & Decreased & No change & & Bowering \& Brodie 1991 \\
\hline Glyptocephalus hynoglossus & NW Atlantic & Increased & Decreased & - & - & Bowering \& Brodie 1991 \\
\hline \multirow[t]{3}{*}{ Pleuronectes platessa } & North Sea & Increased $(>30 \mathrm{~cm})$ & - & - & - & $\begin{array}{l}\text { Rijnsdorp \& van Leeuwen } \\
\text { 1992, } 1996\end{array}$ \\
\hline & North Sea & Increased $(30-40 \mathrm{~cm})$ & - & Decreased & - & Rijnsdorp 1991, 1993 \\
\hline & North Sea & No change $(50 \mathrm{~cm})$ & - & - & - & Rijnsdorp 1991 \\
\hline Solea solea & North Sea & Increased & No change & Increased & - & $\begin{array}{l}\text { Millner \& Whiting 1996; } \\
\text { Rijnsdorp et al. } 1991\end{array}$ \\
\hline Mycteroperca microlepis & W Atlantic & - & - & - & Decreased & Coleman et al. 1996 \\
\hline Mycteroperca phenax & W Atlantic & - & - & - & Decreased & Coleman et al. 1996 \\
\hline Rhomboplites aurorubens & W Atlantic & - & Decreased & Decreased & - & Zhao \& McGovern 1997 \\
\hline Pagrus pagrus & W Atlantic & Increased & - & - & - & Harris \& McGovern 1997 \\
\hline \multicolumn{7}{|l|}{ LOBSTERS } \\
\hline Jasus lalandii & SE Atlantic & Increased & - & Increased & - & $\begin{array}{l}\text { Beyers \& Goosen 1987; } \\
\text { Pollock \& Goosen } 1991\end{array}$ \\
\hline Fasus tristani & SE Atlantic & Increased & - & Increased & - & Pollock 1991 \\
\hline \multirow[t]{2}{*}{ Panulirus longipes cygnus } & Pacific & Increased & - & Increased & - & Chittleborough 1976 \\
\hline & & - & - & Decreased & - & Polovina 1989 \\
\hline
\end{tabular}


However, there are studies of exploited fish populations where no correlation between growth rates and density has been detected (De Veen 1976; Rauck \& Zijlstra 1978; Jones 1987b; Rijnsdorp \& van Beek 1991; Helser \& Almeida 1997). In these studies, differences in growth rates were attributed to variations in environmental factors such as temperature, oxygen and food availability, endogenous patterns of growth determined genetically, or to differences in interspecific interactions, amongst others.

The few studies available that compare growth rates of marine organisms in protected and exploited areas have not reported differences that could be attributed to variations in population density. Buxton (1993) compared the growth of two sparids, Chrysoblephus laticeps and C. cristiceps, in a large MPA with areas adjacent to it and found no differences in growth of $C$. laticeps but significant differences in the growth of $C$. cristiceps with higher growth rates in the protected area. Similarly, a study of the spatio-temporal variability of growth rates of juveniles of three Diplodus species in the Mediterranean did not show differences between fished and unfished areas (Planes et al. 1999, 2000). Growth rates of the spiny lobster Panulirus argus in a Florida MPA were nearly twice those observed in adjacent fished areas in spite of its high density and appear to reflect optimal habitat conditions in the MPA (Davis \& Dodrill 1989).

\section{Natural mortality}

Fishery theory assumes that juvenile mortality is densitydependent while adult mortality is density-independent (Charnov 1986) and the same notion has been developed for coral reef fishes (Warner \& Chesson 1985). In fact, densitydependent mortality during the juvenile phase has been considered to be the compensatory mechanism that attenuates variability in year class strength in marine fishes (Myers \& Cadigan 1993a). Growth is a prime factor affecting survival of larval and juveniles phases of marine species due to there being a positive relationship between mortality and size (Lambert \& Ware 1984; Butler \& Nishimoto 1997; Gallego \& Heath 1997). The main biological processes that enhance density-dependent mortality during the early stages are predation and competition, the latter in turn leading to higher risk of predation (Lambert \& Ware 1984; Wootton 1990; Pollock 1991 a, b; Myers \& Cadigan 1993b; Leggett \& Deblois 1994; Hixon \& Carr 1997). Another process considered to increase mortality is disease enhancement at high densities (Letourneur et al. 1998).

Density-dependent changes in mortality have not been reported in adults of marine fishes or macroinvertebrates. Conversely density-dependent variations in juvenile mortality have been documented in exploited populations of fishes such as Gadus morhua, Pleuronectes platessa, Merlangius merlangus, Solea solea, Merluccius productus and Epinephelus merra (Beverton \& Illes 1992a, b; Myers \& Cadigan 1993b; Butler \& Nishimoto 1997; Letourneur et al. 1998; Pastoors et al. 1998), as well as for the spiny lobsters Panulirus cygnus, $P$. marginatus and Jasus spp. (Chittleborough \& Phillips 1975;
Polovina 1989; Pollock 1993). Experimental studies of density-dependent processes in juvenile reef fishes (mainly Pomacentridae and Labridae species) have yielded divergent results. Mortality was found to be density-dependent in some cases (Jones 1987b, 1988; Forrester 1990; Booth 1995; Hixon \& Carr 1997) and density-independent in others (Doherty 1983; Victor 1986; Jones 1987a). These discrepancies could reflect intraspecific variation in regulatory mechanisms, or could be partially explained by the different developmental stages and social status of the groups studied (Booth 1995). To complicate matters further, the few studies that report density-dependent changes in mortality rates have found opposing results, that is, increased (Booth 1995) and reduced (Jones 1987b, 1988; Forrester 1990) survivorship with increased density.

In MPAs, increased mortality of juveniles may also be expected due to the high biomass of predators. Few studies have addressed changes in natural mortality in protected populations. Buxton (1993) found higher natural mortality in two sparid fishes, C. laticeps and C. cristiceps, in a MPA when compared with exploited areas. A study of juvenile fishes of the genus Diplodus in a North-western Mediterranean MPA showed that the mortality of recently-settled fish is densitydependent; however, no relationship was found with the level of protection because the density of settled juveniles was similar in the protected and the exploited areas, and habitat segregation existed between juveniles and adults (Macpherson et al. 1997). In the case of sedentary and territorial fish species that settle directly into the adult habitat, survival may be severely limited through predation by, or competition for suitable substrate with adult conspecifics. Such a density-compensatory mechanism has been hypothesized for Serranus cabrilla in North-western Mediterranean MPAs (Planes et al. 2000). However, density-dependent (intra-cohort or inter-cohort competition or predation) and density-independent (interspecific relationships) sources of mortality could be very difficult to separate in MPAs.

In unfished populations of the abalone Haliotis laevigata, density-dependent mortality was found to be due to the combined effect of increased competition for shelter and predator-prey interactions (Shepherd 1990). However, intraspecific competition does not need always to increase with density, as shown by Tegner and Dayton (1976) who simulated the effects of fishing on the sea urchin Strongylocentrotus franciscanus, and observed higher survival of juveniles in areas of high adult density because they provide the needed protective canopy.

\section{Reproductive traits}

Age or size at maturity, timing of sex-change and size-specific fecundity have been described, or suggested, as the reproductive variables that could change as reproductive potential is lost through a reduction in stock size (Wootton 1990; Trippel 1995). Changes in these traits would tend to offset the decline in population egg production as a result of reduced spawning stock biomass (Wootton 1990; Pollock 
1995 ) and is thought to contribute to preventing some stocks from reaching extremely low levels (Trippel 1995).

The effect of a change in population density on the age and size at maturity depends primarily on the effects of density on growth and mortality during the juvenile phases (Stearns \& Crandall 1984). A number of studies have demonstrated that growth rates and maturity are closely related. Thus, populations of a given species may differ in the age or size at maturity in relation to latitude, food supply or any environmental or social factor that affect the rate of growth (Stearns \& Crandall 1984; Hartnoll 1985; Trippel et al. 1997). Stearns and Crandall (1984) modelled the possible trajectories of age and size of first maturity of organisms under an environmental stress that results in slower growth. Their model shows that a reduction in growth rate (as it could occur when population density increases) brings a delayed age at maturity. However, as a change in growth rate produces a change in size-at-age, the size-at-maturity could be smaller, equal or, more rarely, larger. No study has apparently yet assessed change of this reproductive trait in MPAs, however a decrease in the age at first maturity in fish populations in response to a progressive reduction in abundance induced by exploitation has been widely documented (Table 2 ; review in Trippel 1995). Most studies have reported maturation at a younger age accompanied by a decline in the size-at-maturity (Rijnsdorp 1991, 1993; Zhao \& McGovern 1997; SaboridoRey \& Junquera 1998), but some have reported no changes in size-at-maturity (Table 2). In spiny lobsters, maturity has been thought of as age-specific rather than size-specific (Beyers \& Goosen 1987; Pollock \& Goosen 1991) and both increases and reductions in size-at-maturity have been reported in association with reductions in population density (Table 2). It should be noted that since both short-term fishing effects (phenotypic changes) and long-term fishing effects (genotypic changes) may influence age-at-maturity in a similar manner, some of the reported reductions in age-atmaturity in exploited populations could be densityindependent and caused by genetic selection towards early-maturing individuals (Jorgensen 1990; Pollock 1995; Harris \& McGovern 1997; Zhao \& McGovern 1997).

Timing of sex change is also considered a plastic trait in some sequential hermaphrodite fishes, where it seems to be under exogenous control. It has been suggested that sociallymediated sex change occurs either by assessment of relative size or of sex-ratio (Shapiro 1981; Ross 1990). Reductions in the size and/or age of sex reversal have been documented in depleted populations of Pagrus pagrus (Harris \& McGovern 1997), Mycteroperca microlepis and M. phenax (Coleman et al. 1996) as a result of the change in sex-ratio induced by sizeselective or sex-selective fishing. The same trend, namely reduction in the size and age of sex change, has been observed at high population densities, both in experimental and natural populations of labrid and scarid fish species (Warner \& Hoffman 1980a, b; Warner 1982; Lejeune 1987; van Rooij et al. 1996). Conversely E. morio has not experienced reduction in the size of sex change after 25 years of exploitation
(Coleman et al. 1996). A high proportion of young males and transitional-sex individuals of Plectropomus leopardus was found in fished versus unfished reefs of the Great Barrier Reef (Ferreira \& Russ 1995). Harmelin et al. (1995) also reported that fishing pressure modified the social conditions in a Mediterranean wrasse, Coris julis, population and induced earlier sex change. Buxton (1993) reported that sex ratios outside a MPA in South Africa were skewed towards the females in the protogynus sparid fish $C$. cristiceps and $C$. laticeps. Size at sex change was also significantly smaller for C. cristiceps, but not so for C. laticeps. Fishing removes both males and dominant females in $C$. cristiceps and would provide a greater opportunity for sex change in progressively smaller females whereas some of the mature age classes of $C$. laticeps were not recruited to the fishery (Buxton 1993).

Density-dependent regulation of fecundity may also serve to stabilize marine populations. If growth rates increase in depleted populations, size-specific fecundity is also expected to increase (Kjesbu et al. 1991; Rijnsdorp 1991, 1993; Rijnsdorp et al. 1991; Trippel 1995). Although the existence of this change has been established experimentally, field evidence for density-dependent regulation of fecundity is often equivocal and only a few studies provide conclusive data. Rijnsdorp $(1991,1993)$ reported an increase in sizespecific fecundity for the smaller size classes of $P$. platessa since 1900 and a reduction in this trait during the Second World War when fishing was substantially reduced; lack of correlation between fecundity and ovary weight was interpreted as a change in the energy allocation from a small number of large eggs to a large number of small eggs. Koslow et al. (1995) reported a sharp increase in relative fecundity when a population of the long-lived teleost fish Hoplostethus atlanticus was fished down to $50 \%$. This compensatory response has also been reported in other fish species (Table 2). Similarly, DeMartini et al. (1993) reported an increase of $16 \%$ in size-specific fecundity of the spiny lobster $P$. marginatus after 14 years of exploitation. In the lobster $P$. cygnus off Western Australia, Chittleborough (1976, 1979) observed an increase in the frequency of spawning in association with reduced population density.

It is important to note that, contrary to the above, in some cases a reduction of fertilization or mating success has been observed at low population densities; this is the so-called Allee effect. This depensatory density-dependent response may be potentially important in marine organisms that reproduce by releasing gametes into the environment. In some marine invertebrates, the proportion of released eggs that become fertilized has been shown to be density-dependent (Penningthon 1985; Levitan 1991; Levitan et al. 1992). Also, the loss of reproductive potential due to rarity may be important in marine organisms that aggregate for spawning since the decline of adults that aggregate is more pronounced than the decrease in density (Shepherd \& Brown 1993; Coleman et al. 1996). 


\section{Biomass export or spillover effects from MPAs}

When the density of a population is higher inside a MPA than in adjacent unprotected areas, random movements are expected to produce a net emigration from the reserve (Rakitin \& Kramer 1996). Furthermore, frequency-dependent models of animal distribution such as the ideal free distribution predict that, when the species fitness is affected by the relationship of population density and resource availability, animals prefer to move away from areas where their density is high (Rakitin \& Kramer 1996). Emigration of individuals from MPAs has been proposed as a potential benefit of MPAs for fisheries management and population replenishment (Russ \& Alcala 1996). Emigration has also been proposed as the explanation for the lack of difference in abundance of some species between MPAs and fished areas reported in some studies (Childress 1997). Kramer and Chapman (1999) examined the implications of coral fish home range size and relocation on MPA function and ability to increase abundance outside. Species with intermediate levels of mobility and of density-dependent space use are predicted to provide the greatest spillover benefits to nearby fisheries (Kramer \& Chapman 1999). Potential emigration could thus be important for non-pelagic fishes and some invertebrates such as lobsters and shrimps. These species may spend enough time inside MPAs to have a significant reduction in fishing mortality while having the ability to move outside MPAs. Highly mobile species like pelagic fish could move easily in and out of MPAs, but additional production of biomass, if any, attributable to protection will be low, and will be related to the time spent in the MPAs (Bohnsack 1992). The stage of development may also be an important determinant of mobility, as in the spiny lobster $P$. argus, where the juveniles may undergo long-range migrations while the adults tend to exhibit site-attached behaviour (Hunt et al. 1991). Sessile or highly sedentary species such as many invertebrates could not emigrate significantly during their adult life. For reef fishes, Roberts and Polunin (1991) concluded that although a considerable potential exists for movement across MPA boundaries, any significant enhancement of fisheries by emigration would be fairly localized around MPAs.

Despite the potential of biomass export from MPAs as a management tool for fisheries and species replenishment, there is remarkably little evidence of this effect so far. In the following sections we review evidence of export from tagrecapture studies, studies of gradients of abundance across MPA boundaries and from commercial fisheries established near or around MPAs.

\section{Evidence from tag-recapture studies}

Some studies have demonstrated that fish or invertebrates tagged and released inside MPAs may be caught outside them (Davis \& Dodrill 1980, 1989; Gitschlag 1986; Yamasaki \& Kuwahara 1990; Hunt et al. 1991; MacDiarmid \& Breen 1993; Attwood \& Bennett 1994; Bohnsack 1998; Goñi et al. in press). However, these kinds of studies usually do not demonstrate that emigration is higher than immigration. Goñi et al. (in press) discuss the difficulties inherent in tagrecapture experiments conducted to assess net movement across MPA boundaries when recapture possibilities (fishing effort) is lower inside than outside the MPA and when fishing effort is not well known. Gitschlag (1986) showed that movement of tagged pink shrimp Penaeus duorarum occurred from a MPA in Florida Bay to open areas with little movement into the MPA. For the grouper E. marginatus in the Port Cros National Park (North-western Mediterranean), Chauvet and Francour (1990) concluded that the population had a constant demographic structure but that up to half of individuals were renewed each year, suggesting that both immigration and emigration occurred.

MacDiarmid and Breen (1993) showed that five years after the creation of a MPA in New Zealand in 1978, the population of the spiny lobster fasus edpardsii had experienced a 4.5-fold increase in abundance with a shift in the proportion of large mature individuals. In the subsequent nine years, the density of the population changed little and the abundance of large males declined. Males of this species move in summer to deeper waters beyond the boundary of the MPA and are caught by commercial fishers specifically targeting these migrants. A similar pattern is hypothesized by Goñi et al. (in press) for P. elephas in a MPA in the western Mediterranean. In the small core area $\left(0.5 \mathrm{~km}^{2}\right)$ of a MPA in the Florida Keys, the density and size structure of the lobster $P$. argus were similar to those in open fished areas and the density was 3 to 6-fold lower than in other larger MPAs of the Keys (Hunt et al. 1991). In all three lobster studies it has been suggested that due to the small size of the areas protected, lobsters move out of the MPAs either during nocturnal foraging or during seasonal migrations and are being removed by the surrounding intense commercial or recreational fisheries. However, although lobster density inside the MPAs was generally higher than outside, density-dependent emigration from protected areas could not be verified. Results of $P$. argus tagging studies in the Dry Tortugas MPA in the Florida Keys revealed a resident adult population that exhibited limited movements between shallow waters in summer and deeper waters in winter. In contrast, MPAs in Florida Bay serve as nursery areas which the juvenile $P$. argus abandon to undergo migrations of up to hundreds of kilometres to enter adult habitats where they are exposed to fishing (Davis \& Dodrill 1980, 1989).

Not all tagging studies have shown movements across MPA boundaries. Some fish species such as grunts (Haemulon spp.) are fairly sedentary and all recaptures were made within a $5 \mathrm{~m}$ radius of the capture/release point (Tupper \& Juanes 1999). Similarly, 93\% of recaptures of the goatfish Mulloides flavolineatus occurred at the release site (Holland et al. 1993). Reduced movement of fishes across MPA boundaries has also been reported in other studies (Buxton \& Allen 1989; Chapman \& Kramer 1999). 


\section{Gradients of abundance across MPA boundaries}

Emigration of fish from MPAs is expected to produce gradients of abundance and mean size across MPA boundaries. Rakitin and Kramer (1996) found that fish trap catches decreased gradually with distance from the centre of a MPA in Barbados, but this gradient of abundance was less evident in visual counts of fishes of trappable sizes, and was not apparent in trap or visual census estimates of abundance for individual species; the MPA protected fishes from fishing mortality but emigration rates were low. Chapman and Kramer (1999) later corroborated these results and attributed low emigration to large expanses of sand between coral reefs that inhibit movements of many reef fishes. Sluka et al. (1997) found that biomass of the grouper E. striatus in the area $5 \mathrm{~km}$ around the boundaries of a Bahamas MPA was more comparable to the biomass inside the MPA than to that in areas further away.

On the basis of underwater visual census monitoring of large predatory coral reef fish, a significant positive correlation was found between mean densities and years of protection both in the Apo marine reserve and in areas outside the reserve in the Philippines after nine years of protection (Russ \& Alcala 1996). This study constitutes the only evidence that biomass export from MPAs could be a density-dependent process, since the ratio of density in the reserve to that outside the reserve increased during the first years of protection and decreased thereafter, but alternative hypotheses could not be rejected.

\section{Evidence from commercial fisheries near MPAs}

It has been noted that fisheries that exploit species with some natural habitat refuge from current fishing techniques appear to be more robust and dependable over time than fisheries on species that have no natural refuges (Beverton \& Holt 1957; Caddy 1990; Dugan \& Davies 1993). Similarly, MPAs, as natural refugia, may increase fish stocks in adjacent areas through emigration of adult, juvenile and larval stages (Alcala \& Russ 1990; McClanahan \& Kaunda-Arara 1996). The best available evidence of fishery enhancement by MPAs is found in the Sumilon Island reserve in the Philippines (Alcala \& Russ 1990). Fish trap catch rates in the non reserve area of the reef increased during a 10 -year period after its creation. At the end of that period, enforcement failed and this resulted in intensive fishing inside the reserve. Two years after protection ceased, total yield decreased to $54 \%$ (relative to the last year of protection) in spite of the expansion of fishing grounds (reserve plus non reserve areas) and catch rates declined by $33 \%$ to $58 \%$ depending on the fishing gear considered. Comparison of catch per unit effort (CPUE) in Sumilon with other exploited reefs showed significant differences before the violation occurred but did not differ during the violation period. The most likely mechanism for the maintenance of high yields in areas adjacent to the reserve was considered to be emigration of adult fishes from the reserve (Alcala $\&$ Russ 1990), which may be a response to a shortage of resources such as food or habitat in the protected area.
The establishment of a MPA that covered $2 \%$ of a fishing ground for snow crabs in Japan resulted in a $46 \%$ increase in mean CPUE in adjacent areas after the fifth year of protection (Yamasaki \& Kuwahara 1990). Fishery enhancement was most evident within $5 \mathrm{~km}$ of the crab MPA, and tag-recapture studies demonstrated male dispersal from the protected area (Yamasaki \& Kuwahara 1990).

When compared with other fishing grounds used by fishers, the CPUE of the artisanal fishery around a MPA in the Western Mediterranean was higher (Mas \& Barcala 1997). The total yield of the small-scale fishery around this MPA did not change significantly after the MPA was created (Mas \& Barcala 1997), but the catch of some highly soughtafter species such as Dentex dentex, E. marginatus, and P. pagrus increased (Ramos et al. 1992; Mas \& Barcala 1997). In contrast, the artisanal catch of Sciaena umbra, also a sought-after species with higher densities inside the MPA (Bayle 1999), declined.

In Kenya, the protection of $65 \%$ of a fishing ground produced a similar reduction in the number of fishers, a decline of $35 \%$ in total fish catch and an increase of $110 \%$ in CPUE (McClanahan \& Kaunda-Arara 1996). Although the catch in the $1-2 \mathrm{~km}$ wide area along the edge of the MPA increased, presumably through spillover, this could not compensate for the loss of a relatively large part of the fishing ground. The low edge-to-area ratio of large MPAs may be partially responsible for the decline in total catch despite increased fish abundance in the MPA (McClanahan \& Kaunda-Arara 1996).

Probably the best fishery evidence of biomass export from MPAs is that often fishing effort is very high at the boundaries of protected areas, suggesting that catch rates are improved close to them (Shorthouse 1990; Craik 1991 in Rowley 1994; McClanahan \& Kaunda-Arara 1996; Goñi et al. in press). In some cases, a change in the attitudes and perceptions of fishers occurs after the protection, also suggesting that commercial catches in nearby areas have improved (Shorthouse 1990; Badalamenti et al. 2000).

\section{Discussion}

It has been largely documented both in tropical and temperate areas that the cessation of fishing leads to increased abundance and changes in the demographic structure of exploited populations due to the combined effects of population and habitat protection. However, populations cannot increase endlessly and resource availability, recruitment, inter-specific and intraspecific interactions, as well as the rates of immigration and emigration, will determine in each case the maximum size that a population can attain inside a MPA. Figure 1 illustrates the main changes and processes that are expected to take place when fishing mortality is reduced and a population is allowed to recover in a MPA. Reduction of fishing mortality should lead to increased survival and to a shift towards bigger and older individuals. This in turn will increase the reproductive potential of the 


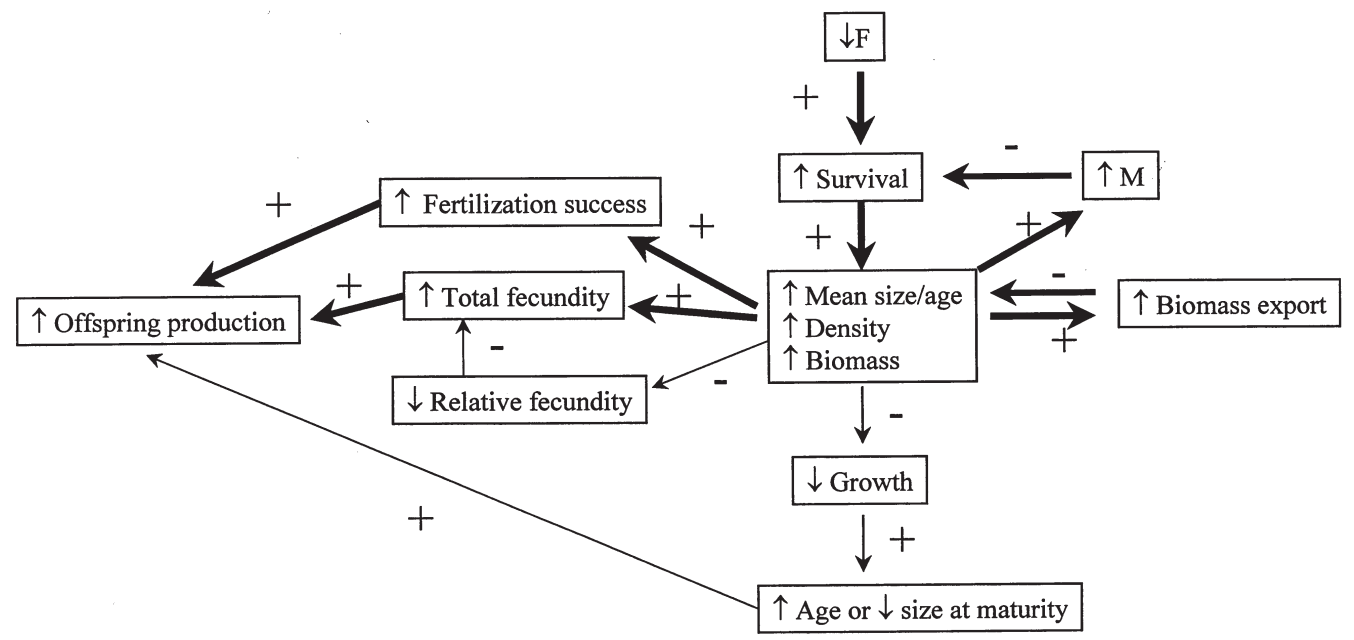

Figure 1 Summary of possible changes in population dynamics following protection of exploited species in MPAs. Plus and minus signs indicate expected responses (increase and decrease, respectively) and bold arrows indicate potentially strong effects.

protected populations. The resulting higher abundance and biomass in the MPA may result in increased competition that may in turn trigger compensatory mechanisms which will tend to dampen the rate of population growth (Fig. 1). Up to now, there are very few long-term series of density estimates in and around MPAs before and after protection to verify this assumption in the context of protected populations.

But, what is the evidence for density-dependent modifications of life-history traits of protected populations? Few studies have been directed at evaluating this question and up to now no evidence has been obtained from comparisons of populations inside and outside of MPAs (Davis \& Dodrill 1989; Buxton 1993; Ferreira \& Russ 1996; Macpherson et al. 1997; Planes et al. 1999). Due to the lack of time-series data of biological variables for the populations studied in MPAs, in general these studies are based on spatial comparisons. Considering the great plasticity of life-history traits of marine species, in particular of growth rates, it is hardly surprising that comparisons of geographically-separated populations have yielded equivocal results. Also, since many MPAs are placed in singular or in exceptional habitats, the results may be interpreted as an absence of density-dependent changes while differences in life-history traits are in fact due to the especially favourable conditions for growth and survival often encountered in MPAs ( $P$. argus in Florida Bay, Everglades National Park; Davis \& Dodrill 1989).

Alternatively, compensatory density-dependent modifications in growth rates and, as a consequence, in age-at-maturity and size-at-maturity have been identified following changes in density induced by fishing or in the case of strong year classes. Density-dependent changes in juvenile natural mortality or in relative fecundity have also been documented in some fish and lobster populations. In populations protected in MPAs, losses of reproductive potential brought about by plausible density-dependent reductions in growth, size-at-maturity or relative fecundity, may be offset by the greater reproductive potential of greater numbers of large individuals. A positive feedback would also be produced in species where high density increases the mating or fertilization success.

The main mechanisms that could control the population size in MPAs are the increase of natural mortality and emigration; independently they are the result of densitydependent or density-independent processes. The type and extent of protected habitats and of the habitats surrounding a MPA in relation to the mobility of the species will determine the relative importance of emigration. For species with intermediate mobility, density-dependent migration from saturated, resource-limited habitat to less crowded areas or density-independent directional or random movements, is expected to regulate the density of the populations inside MPAs. However, in the case of highly-sedentary species or of MPAs encompassing isolated habitats, increase in the density of populations that are not limited by recruitment is expected to trigger increases in mortality to regulate the populations to the carrying capacities of the MPA concerned.

Lack of the necessary types of habitat inside MPAs can exacerbate food and/or space limitation. Recognition of species' resource requirements, such as for food or habitat, has important implications for proper MPA management (Carr \& Reed 1993). There needs to be assurance that MPAs include enough habitat diversity for the feeding activities and habitat requirements of the target species to be satisfied and for the integrity of ecosystem processes. In some marine species, emigration from MPAs could be related to changes in habitat requirements during their life history, as many marine species undergo seasonal and ontogenetic bathymetric or habitat changes (Davis \& Dodrill 1980, 1989; Gitschlag 1986; MacDiarmid \& Breen 1993). Because diversity of habitats is often dependent on area, this condition is closely related to the sizes of MPAs. The effective sizes of MPAs depend on the home ranges and habitat requirements of the 
species to be protected (Bohnsack 1996). Even small MPAs have been shown to protect some species with restricted movements, but large areas may be needed to protect more mobile species (Childress 1997). Also, high perimeter/area ratios will favour biomass export from MPAs and several small MPAs of similar area will always have a higher perimeter/area ratio than a single large MPA, with the shape of the MPA also influencing this ratio. Spillover will also be influenced by the habitats bordering MPAs since many species are habitat-specific. The permeability of MPA edges may be increased by placing MPAs within large patches of similar habitat. Alternatively, spillover may be limited from MPAs that protect separate patches of similar habitat separated by expanses of unfavourable habitat or deep water (Stamps et al. 1987; Rowley 1994; Chapman \& Kramer 1999).

The relevant question for managers is the proportion of the area of distribution of a population that must be protected to produce significant benefit, either in terms of fishery catches or of population recovery in and beyond the MPA. In this respect, a number of different figures have been proposed in recent years, from the $10 \%$ of all marine and coastal areas in the context of marine conservation objectives (Ballantine 1991; Kelleher et al. 1995) to the 20\% or more of the main range of any exploited population in the context of fisheries management objectives (PDT [Plan Development Team] 1990). For reef fish in the Philippines, protection of $10-25 \%$ of the reef area was considered effective (Alcala \& Russ 1990; Russ \& Alcala 1996). A Florida shrimp sanctuary which represented only $6 \%$ of the Tortugas fishing grounds contained $36 \%$ of the total estimated pink shrimp population (Roberts 1986). On the other hand, in Kenya, the protection of $65 \%$ of the fishing area doubled CPUE but reduced total catch and the number of fishers (McClanahan \& KaundaArara 1996). In the Mediterranean, the size of MPAs is generally too small to produce significant increase in the fisheries at regional scales, but higher catch rates around the borders could compensate for the loss of fishing grounds for local fishers and may increase local support for MPAs. Additionally, in many protected areas in the Mediterranean, some kind of fishing is allowed inside them with very small core areas where no fishing is allowed (Boudouresque \& Ribera 1993).

\section{Conclusions}

The reduction of fishing mortality in MPAs tends to produce an increase in the abundance and biomass as well as a shift towards bigger and older individuals of previously-exploited populations. This has been demonstrated mainly for slowgrowing and low-mobility predatory species in populations that have been heavily exploited. Increase in density of adult individuals in MPAs could lead to changes in population dynamics. MPAs must allow exploited species that are susceptible to depensatory responses to reach a minimum density and thus avoid the reduced reproductive potential due to rarity. On the other hand, as densities approach carrying capacities in MPAs, compensatory changes may occur that tend to reduce rates of population growth. Compensatory density-dependent processes could involve changes in biological parameters (reduction in growth, increased mortality or reduction of reproductive success) or increased exportation rates from the MPAs. Most evidence of compensatory changes in biological variables has been found in exploited populations as a result of depletion at high fishing mortalities or in cases of strong year classes. However, these changes are more evident in juveniles than in adults and in closed (freshwater) systems than in open (marine) systems. It is not clear if adults of exploited marine populations are resource limited. If they are not, exploited populations are controlled mainly by density-independent processes, but this could be a consequence of the depleted state of most exploited populations. MPAs could be a useful tool for testing these hypotheses. This review of the available evidence of density-dependent changes in life-history traits highlights the difficulty of separating density-dependent and density-independent processes that control the size of marine populations.

If we assume that resources may become limiting inside MPAs, it is plausible that, if suitable habitats exist, mobile species will tend to search for resources outside the protected areas, leading to exportation of biomass to areas open to fisheries. Given the small size of most MPAs, in particular in the Mediterranean Sea, emigration from the MPAs is potentially the main mechanism that will control the biomass inside, regardless of whether it results from density-dependent or density-independent responses. This process has important implications for the use of MPAs as fisheries management tools. Up to now, some evidence of biomass export from protected areas is available and, in some cases, indicates significant changes in the yields of fisheries immediately around MPAs. However, it is not possible to establish whether this export of adult individuals is a response to resource limitation inside the protected area or of random movements across MPA boundaries.

\section{Acknowledgements}

Financial support was provided by the EU CEC DGXII MAST III contract number: MAS3-ct97-0155.

\section{References}

Alcala, A.C. \& Russ, G.R. (1990) A direct test of the effects of protective management on abundance and yield of tropical marine resources. Fournal du Conseil International pour l'Exploration de la Mer 46: 40-7.

Arias-González, J.E. (1998) Trophic models of protected and unprotected coral reef ecosystems in the South of the Mexican Caribbean. Fournal of Fish Biology 53 (Suppl. A): 236-55.

Arias-González, J.E., Delesalle, B., Salvat, B. \& Galzin, R. (1997) Trophic functioning of the Tiahura reef sector, Moorea Island, French Polynesia. Coral Reefs 16: 231-46.

Attwood, C.G. \& Bennett, B.A. (1994) Variation in dispersal of 
Galjoen (Coracius capensis) (Teleostei: Coracinidae) from a marine reserve. Canadian Fournal of Fisheries and Aquatic Sciences 51: 1247-57.

Ault, T.R. \& Johnson, C.R. (1998) Spatially and temporally predictable fish communities on coral reefs. Ecological Monographs 68(1): 25-50.

Badalamenti, F., Ramos, A.A., Voultsiadou, E., Sánchez-Lizaso, J.L., D’Anna, G., Pipitone, C., Mas, J., Ruiz Fernandez, J.A., Whitmarsh, D. \& Riggio, S. (2000) Cultural and socio-economic impacts of Mediterranean marine protected areas. Environmental Conservation 27(2): 110-25.

Ballantine, W.J. (1991) Marine Reserves for New Zealand. University of Auckland Leigh Laboratory Bulletin 25: 42.

Bannister, R.C.A. (1978) Changes in plaice stocks and plaice fisheries in the North Sea. Rapports et Proces Verbaux des Réunions du Conseil International pour l'Exploration de la Mer 172: 86-101.

Bayle, J.T. (1999) Ictiofauna de la Reserva Marina de Tabarca: evaluación de las medidas de protección. Ph.D. thesis, University of Alicante: 349 pp.

Bayle, J.T. \& Ramos-Espla, A.A. (1993) Some population parameters as bioindicators for assessing the fish assemblage evolution in a marine reserve. In: Qualité du Milieu Marin Indicateurs Biologiques et Physico-chimiques, ed. C.F. Boudouresque, M. Avon \& C. Pergent-Martini, pp. 189-214. Marseille: GIS Posidonie Publication.

Bell, J.D. (1983) Effects of depth and marine reserve fishing restrictions on the structure of a rocky reef fish assemblage in the North-Western Mediterranean Sea. Fournal of Applied Ecology 20: 357-69.

Beverton, R.J.H. \& Holt, S.J. (1957) On the Dynamics of Exploited Fish Populations. UK Ministry of Agriculture Fisheries and Food Investigation Series 2: 19.

Beverton, R.J.H. \& Iles, T.C. (1992a) Mortality rates of O-group plaice (Pleuronectes platessa L.), dab (Limanda limanda L.) and turbot (Scophthalmus maximus L.) in European waters. II Comparison of mortality rates and construction of life-table for O-group plaice. Netherlands Fournal of Sea Research 29: 49-59.

Beverton, R.J.H. \& Iles, T.C. (1992b) Mortality rates of O-group plaice (Pleuronectes platessa L.), dab (Limanda limanda L.) and turbot (Scophthalmus maximus L.) in European waters. III Density-dependence of mortality rate in O-group plaice and some demographic implications. Netherlands Fournal of Sea Research 29: 61-79.

Beyers, C.J. \& Goosen, P.C. (1987) Variation in fecundity and sexual maturity of female rock lobster Fasus lalandii in the Benguela ecosystem. In: Benguela and comparable ecosystems, ed. A.I.L. Payne, J.A. Gullard \& J.K. Brink. South African Fournal of Marine Science 5: 513-21.

Binche, J.L. (1985) Evolution de la faune ichtyologique de la Resérve Intégrale du Cap Rederis depuis 1980. Unpublished report, Réserve Naturalle Marine de Cerbère-Banyuls-sur-Mer: 9 pp.

Bohnsack, J.A. (1982) Effects of piscivorous predator removal on coral reef fish community structure. In: Gutshop '81: Fish Food Habits and Studies, ed. G.M. Caillet \& C.A. Simenstad, pp. 258-67. Seattle: University of Washington.

Bohnsack, J.A. (1992) Reef resources habitat protection: the forgotten factor. In: Stemming the Tide of Coastal Fish Habitat Lost, ed. R.H. Strout. Marine Recreational Fisheries 14: 117-29.

Bohnsack, J.A. (1996) Maintenance and recovery of reef fishery productivity. In: Reef Fisheries, ed. N.V.C. Polunin \& C.M. Roberts, pp. 283-313. London: Chapman \& Hall.

Bohnsack, J.A. (1998) Marine reserves: lessons from Florida. In: Marine Harvest Refugia for West Coast Rockfish: a Workshop, ed. M.M. Yoklavich. NOAA Technical Memorandum National Marine Fisheries Service-S.W. Fisheries Science Center 255: 89-99.

Booth, D.J. (1995) Juvenile groups in a coral-reef damselfish: density-dependent effect on individual fitness and population demography. Ecology 76(1): 91-106.

Boudouresque, C.F. \& Ribera, M.A. (1993) Les espèces et les espaces protégés marins en Méditerranée, situation actuelle, problèmes et priorités. Les Zones Protégées en Méditerranée. Actes de Colloque. Tunis - Novembre 1993, pp. 94-141. Tunis: Centre d'Etude, de Recherches et de Publications (CERP) and Comité pour les Etudes Méditerranéenne (CEM).

Bowering, W.R. \& Brodie, W.B. (1991) Distribution of commercial flatfishes in the Newfoundland-Labrador region of the Canadian Northwest Atlantic and changes in certain biological parameters since exploitation. Netherland Fournal of Sea Research 27: 407-22.

Bruggeman, J.H., van Oppen, J.H. \& Breeman, A.M. (1994) Foraging by the stoplight parrotfish Sparisoma viride. I. Food selection in different, socially determined habitats. Marine Ecology Progress Series 106: 41-55.

Butler, J.L. \& Nishimoto, R.N. (1997) Growth and cohort dynamics of larval Pacific hake (Merluccius productus). CALCOFI Reports 38: $63-8$.

Buxton, C.D. (1993) Life-history changes in exploited reef fishes on the east coast of South Africa. Environmental Biology of Fishes 36: 47-63.

Buxton, C.D. \& Allen, J.A. (1989) Mark and recapture studies of two reef sparids in the Tsitsikamma Coastal National Park. Koeode 32: 39-45.

Caddy, J.F. (1986) Modelling stock-recruitment processes in Crustacea: some practical and theoretical perspectives. Canadian Journal of Fisheries and Aquatic Sciences 43: 2330-44.

Caddy, J.F. (1990) Options for the regulation of Mediterranean demersal fisheries. Natural Resource Modeling 4: 427-75.

Carr, M.H. \& Reed, D.C. (1993) Conceptual issues relevant to marine harvest refuges: examples from temperate fish. Canadian Fournal of Fisheries and Aquatic Sciences 50: 2019-28.

Chapman, M.R. \& Kramer, D.L. (1999) Gradients in coral reef fish density and size across the Barbados Marine Reserve boundary: effects of reserve protection and habitat characteristics. Marine Ecology Progress Series 181: 81-96.

Charnov, E.L. (1986) Life history evolution in a recruitment population. Why are adult mortality rates constant? Oikos 47: 129-34.

Chauvet, C. \& Francour, P. (1990) Les merous E. guaza du Parc National de Port-Cros (France): aspets socio-demographiques. Bulletin Société Zoologique de France 114(4): 5-13.

Childress, M.J. (1997) Marine reserves and their effects on lobster populations: report from a workshop. Marine and Freshmater Research 48: 1111-14.

Chittleborough, R.G. (1976) Breeding of Panulirus longipes cygnus George under natural and controlled conditions. Australian Fournal of Marine and Freshmater Research 27: 499-516.

Chittleborough, R.G. (1979) Natural regulations of the population of Panulirus longipes cygnus George and responses to fishing pressure. Rapports et Procès-Verbaux des Réunions du Conseil International pour l'Exploration de la Mer 175: 217-22.

Chittleborough, R.G. \& Phillips, B.F. (1975) Fluctuation of year- 
class strength and recruitment in the Western rock lobster Panulirus longipes (Milne-Edwards). Australian Fournal of Marine and Freshmater Research 26: 317-28.

Christensen, V. \& Pauly, D. (1992) ECOPATH II - a software for balancing steady-state ecosystem models and calculating network characteristics. Ecological Modelling 61: 169-85.

Christensen, V. \& Pauly, D. (1998) Changes in models of aquatic ecosystems approaching carrying capacity. Ecological Applications 8(1) Suppl: S104-109.

Coleman, F.C., Koening, C.C. \& Collins, L.A. (1996) Reproductive styles of shallow water groupers in eastern Gulf of Mexico and consequences of fish spawning aggregations. Environmental Biology of Fishes 47: 129-41.

Cushing, D.H. (1995) Population Production and Regulation in the Sea. A Fisheries Perspective. Cambridge, UK: Cambridge University Press: 354 pp.

Daan, N., Bromley, P.M., Hislop, J.R.G. \& Nielsen, N.A. (1990) Ecology of North Sea fishes. Netherlands Journal of Sea Research 26: 343-86.

Davis, G.E \& Dodrill, J.W. (1980) Marine parks and sanctuaries for spiny lobster fisheries management. Proceedings of the Gulf Caribbean Fisheries Institute 32: 194-207.

Davis, G.E. \& Dodrill, J.W. (1989) Recreational fishery and population dynamics of spiny lobsters, Panulirus argus, in Florida Bay, Everglades National Park, 1977-1980. Bulletin of Marine Science 44(1): 78-88.

De Veen, J.F. (1976) On changes in some biological parameters in the North Sea sole. Fournal du Conseil International pour l'Exploration de la Mer 37: 60-90.

DeMartini, D.M.E., Ellis, D.M. \& Honda, V.A. (1993) Comparisons of spiny lobster Panulirus marginatus fecundity, egg size, and spawning frequency before and after exploitation. Fishery Bulletin (US) 91: 1-7.

Doherty, P.J. (1983) Tropical territorial damselfishes: is density limited by aggression or recruitment. Ecology 64(1): 176-90.

Dufour, V., Jouvenel, J.Y. \& Galzin, R. (1995) Study of a Mediterranean reef fish assemblage. Comparison of population distribution between depths in protected and unprotected area over one decade. Aquatic Living Resources 8: 17-25.

Dugan, J.E. \& Davies, G.E. (1993) Applications of marine refugia to coastal fisheries management. Canadian Fournal of Fisheries and Aquatic Sciences 50: 2029-42.

Edgar, G.J. (1993) Measurement of the carrying capacity of benthic habitats using a metabolic-rate based index. Oecologia 95 ; 115-21.

Ferreira, B.P. \& Russ, G.R. (1995) Population structure of the leopard coral grouper Plectropomus leopardus, on fished and unfished reefs off Townsville, Central Great Barrier Reef, Australia. Fishery Bulletin 93: 629-42.

Forrester, G.E. (1990) Factors influencing the juvenile demography of a coral reef fish population. Ecology 71: 1666-81.

Francour, P. (1991) The effect of protection level on a coastal fish community at Scandola, Corsica. Revue d'Ecologie (Terre et Vie) 46: 65-81.

Francour, P. (1994) Pluriannual analysis of the reserve effect in ichthyofauna in the Scandola natural reserve (Corsica, Northwestern Mediterranean). Oceanologica Acta 17(3): 309-17.

Friedlander, A.M. \& Parrish, J.D. (1998) Habitat characteristics affecting fish assemblages on a Hawaiian coral reef. Fournal of Experimental Marine Biology and Ecology 224: 1-30.

Gallego, A. \& Heath, M. (1997) The effect of growth-dependent mortality, external environment and internal dynamics on larval fish otolith growth: an individual-based modelling approach. Fournal of Fish Biology 51(A): 121-34.

García Charton, J.A. \& Pérez Ruzafa, A. (1998) Correlation between habitat structure and a rocky reef fish assemblage in the southwest Mediterranean. P.S.Z.N.I. Marine Ecology 19: 111-28.

García Rubies, A. (1997) Estudi ecològic de les poblacions de peixos litorals sobre subtrat rocós a la Mediterrània Occidental: Efecte de la fondària, el substrat, l'estacionalitat, i la protecció. $\mathrm{Ph} . \mathrm{D}$ thesis, University of Barcelona: $261 \mathrm{pp}$.

García Rubies, A. \& Zabala, M. (1990) Effects of total fishing prohibition on the rocky fish assemblage of Medes Islands marine reserve. Scientia Marina 54(4): 317-28.

Gitschlag, G.R. (1986) Movement of pink shrimp in relation to the Tortugas sanctuary. North America Fournal of Fisheries Management 6: 328-38.

Goñi, R. (1998) Ecosystem effects of marine fisheries: an overview. Coastal \& Ocean Management 40: 37-64.

Goñi, R., Reñones, O., Quetglas, A. \& Mas, J. (in press) Effects of protection on the abundance and distribution of red lobster (Palinurus elephas, Fabricius 1787) in the marine reserve of Columbretes Islands (Western Mediterranean): preliminary results of a study. In: 1st International Workshop on Marine Reserves. Murcia (Spain), 1999.

Harmelin, J.G., Bachet, F. \& Garcia, F. (1995) Mediterranean marine reserves: fish indices as test of protection efficiency. P.S.Z.N.I. Marine Ecology 16: 233-50.

Harris, P.J. \& McGovern, J.C. (1997) Changes in the life history of red porgy, Pagrus pagrus from the southeastern United States, 1972-1994. Fishery Bulletin 95: 732-47.

Hartnoll, R.G. (1985) Growth, sexual maturity and reproductive output. Factors in adult growth. Vol. 3. In: Crustacean Issues, ed. A.M. Wenner. Rotterdam: Balkema: 362 pp.

Hastings, A. \& Botsford, L.W. (1999) Equivalence in yield from marine reserves and traditional fisheries management. Science 284: 1536-7.

Helser, T.E. \& Almeida, F.P. (1997) Density dependent growth and sexual maturity of silver hake in the north-west Atlantic. Fournal of Fish Biology 51: 607-23.

Hixon, M.A. \& Beets, J.P. (1993) Predation, prey refuges, and the structure of coral-reef fish assemblages. Ecological Monographs 63: 77-101.

Hixon, A. \& Carr, M.H. (1997) Synergistic predation, density dependence and population regulation in marine fish. Science 277 : 946-9.

Holland, K.N., Peterson, J.D., Lowe, C.G. \& Wetherbee, B.M. (1993) Movements, distribution and growth rates of the white goatfish Mulloides flavolineatus in a fishery conservation zone. Bulletin of Marine Science 52(3): 982-92.

Hunt, J.H., Matthews, T.R., Forucci, D., Hedin, B.S. \& Bertelsen, R.D. (1991) Management implications of trends in the population dynamics of the Caribbean spiny lobster, Panulirus argus at Looe Key National Marine Sanctuary. Unpublished final report, NOAA Contract 50-DGNC-6-0093.

Jennings, S. \& Polunin, N.V.C. (1996) Effects of fishing effort and catch rate upon the structure and biomass of Fijian reef fish communities. Fournal of Applied Ecology 33: 400-12.

Jennings, S. \& Polunin, N.V.C. (1997) Impacts of predator depletion by fishing on the biomass and diversity of non-target reef fish communities. Coral Reefs 16: 71-82.

Jennings, S., Grandcourt, E.M. \& Polunin, N.V.C. (1995) The 
effects of fishing on the diversity, biomass and trophic structure of Seychelles reef fish communities. Coral Reefs 14: 225-35.

Jones, G.P. (1987a) Competitive interactions among adults and juveniles in a coral reef fish. Ecology 68(5): 1534-47.

Jones, G.P. (1987b) Some interaction between residents and recruits in two coral reef fishes. Fournal of Experimental Biology and Ecology 114: 169-82.

Jones, G.P. (1988) Experimental evaluation of the effects of habitat structure and competitive interactions on juveniles of two coral reef fishes. Fournal of Experimental Marine Biology and Ecology 123: 115-26.

Jones, G.P., Cole, R.C. \& Battershill, C.N. (1993) Marine reserves: do they work? In: Proceedings of the Second International Temperate Reef Symposium, 7-10 January 1992, ed. C.N. Battershill, D.R. Schiel, G.P. Jones, R.G. Creese \& A.B. MacDiarmid, pp. 29-45. Wellington, New Zealand: NIWA Marine.

Jones, R. (1983) An investigation of North Sea haddock (Melanogrammus aeglefinus) length-at-age data, with particular reference to the effect on growth of the outstanding year classes of 1962 and 1967. Fournal du Conseil International pour l'Exploration de la Mer 41: 50-62.

Jones, R. (1989) Towards a general theory of population regulation in marine teleosts. Fournal du Conseil International pour l'Exploration de la Mer 45: 176-89.

Jorgensen, R. (1990) Long-term changes in age at sexual maturity of Northeast Atlantic cod. Fournal du Conseil International pour l'Exploration de la Mer 4: 50-62.

Jouvenel, J.Y. (1997) Ichtyofaune de la côte rocheuse des Albères (Méditerranée, NO, France). Doctoral thesis, Ecole Pratique des Hautes Etudes, Perpignan, France: 265 pp.

Kelleher, G., Bleakley, C. \& Wells, S. (1995) A Global Representative System of Marine Protected Areas, Vols. I-IV. Great Barrier Reef Marine Park Authority, the World Bank and IUCN, Canberra, Australia, Washington, DC, USA and Gland, Switzerland.

Kjesbu, O.S., Klungsoyr, J., Kryvi, H., Witthames, P.R. \& Greer Walker, M. (1991) Fecundity, atresia and egg size of captive Atlantic cod (Gadus morhua) in relation to proximate body composition. Canadian Fournal of Fisheries and Aquatic Sciences 48: 2333-43.

Koslow, J.A., Bell, J., Virtue, P. \& Smith D.C. (1995) Fecundity and its variability in orange roughy: effects of population density, condition, egg size, and senescence. Fournal of Fish Biology 47: 1063-80.

Kramer, D.L. \& Chapman, M.R. (1999) Implications of fish home range size and relocation for marine reserve function. Environmental Biology of Fishes 55: 65-79.

Lambert, T.C. \& Ware, D.M. (1984) Reproductive strategies of demersal and pelagic fish. Canadian Fournal of Fisheries and Aquatic Sciences 41: 1565-9.

Landa, J. (1999) Density-dependent growth of four spot megrim $(L$. boscii) in the northern Spanish shelf. Fisheries Research 40: 267-76.

Larkin, P.A. (1996) Concepts and issues in marine ecosystem management. Reviems in Fish Biology and Fisheries 6: 139-64.

Leggett, W.C. \& Deblois, E. (1994) Recruitment in marine fishes: is it regulated by starvation and predation in the egg and larval stages? Netherlands fournal of Sea Research 32(2): 119-34.

Lejeune, P. (1987) The effect of local stock density on social behaviour and sex change in the Mediterranean labrid Coris julis. Environmental Biology of Fishes 18(2): 135-41.
Letourneur, Y., Chabanet, P.M., Vigliola, L. \& Harmelin-Vivien, M. (1998) Mass settlement and post-settlement mortality of Epinephelus merra (Pisces: Serranidae) on Reunion coral reefs. Fournal of the Marine Biology Association of the UK 78: 307-19.

Levitan, D.R. (1991) Influence of body size and population density on fertilization success and reproductive output in a freespawning invertebrate. Biological Bulletin (Woods Hole) 181: 261-8.

Levitan, D.R., Sewell, M.A. \& Chia, F.S. (1992) How distribution and abundance influence fertilization success in the sea urchin Strongylocentrotus franciscanus. Ecology 73(1): 248-54.

MacDiarmid, A.B. \& Breen, P.A. (1993) Spiny lobster population change in a marine reserve. In: Proceedings of the Second International Temperate Reef Symposium, ed. C.N. Battershill, D.R. Schiel, G.P. Jones, R.G. Creese \& A.B. MacDiarmid, pp. 47-56. Wellington, New Zealand: NIWA Marine.

Macpherson, E., Biagi, F., Francour, P., García Rubies, A., Harmelin, J., Harmelin-Vivien, M., Jouvenel, J.Y., Planes, S., Vigliola, L. \& Tunesi, L. (1997) Mortality of juvenile fishes of the genus Diplodus in protected and unprotected areas in the western Mediterranean Sea. Marine Ecology Progress Series 160: $135-47$.

Martínez Hernández, J.M. (1997) La pesca artesanal de El Campello (Alicante, SE Ibérico): Caracterización y elementos para una ordenación. Ph.D. thesis, University of Alicante: $250 \mathrm{pp}$.

Mas, J. \& Barcala, E. (1997) Estudio del efecto reserva en base al seguimiento de estadística pesquera de la flota artesanal en su área de influencia. Unpublished report, IEO Centro Oceanográfico de Murcia: 44 pp.

McClanahan, T.R. (1994a) Kenyan coral reef lagoonal fishes: associations with reef management, substrate complexity, and sea urchins. Coral Reefs 13: 231-41.

McClanahan, T.R. (1994b) A coral reef ecosystem-fisheries model: impacts of fishing intensity and catch selection on reef structure and processes. Ecological Modelling 80: 1-19.

McClanahan, T.R. \& Kaunda-Arara, B. (1996) Fishery recovery in a coral reef marine park and its effects on the adjacent fishery. Conservation Biology 10(4): 1187-99.

Menge, B.A. (1992) Community regulation: under what conditions are bottom-up factors important on rocky shores? Ecology 73(3): 755-65.

Millner, R.S. \& Whiting, C.L. (1996) Long term changes in growth and population abundance of sole in the North Sea from 1940 to the present. ICES Journal of Marine Science 53: 1185-95.

Myers, R.A. \& Cadigan, N.G. (1993a) Is juvenile natural mortality in demersal fish variable? Canadian Journal of Fisheries and Aquatic Sciences 50: 1591-8.

Myers, R.A. \& Cadigan, N.G. (1993b) Density-dependent juvenile mortality in marine demersal fish. Canadian Fournal of Fisheries and Aquatic Sciences 50: 1576-90.

Pastoors, M.A., Rijnsdorp, A.D. \& van Beek, F.A. (1998) Evaluation of the effect of a closed area in the North Sea ('plaice box') on the stock development of plaice (Pleuronectes platessa). ICES. CM (Council Meeting). U: 2.

PDT (Plan Development Team) (1990) The potential of marine fishery reserves for reef management in the US Southern Atlantic. NOAA Technical Memorandum NMFS-SEFC-261: 40 pp.

Pennington, J.T. (1985) The ecology of fertilization of echinoid eggs: the consequences of sperm dilution, adult aggregations, and 
synchronous spawning. Biological Bulletin (Woods Hole) 169: 417-30.

Pianka, E.R. (1981) Competition and niche theory. In: Theoretical Ecology, ed. R. May, pp. 167-96. Sunderland, MA: Sinauer.

Pinnegar, J.K., Polunin, N.V.C., Francour, P., Badalamenti, F., Chemello, R., Harmelin-Vivien, M.-L., Hereu, B., Milazzo, M., Zabala, M., D'Anna, G. \& Pipitone, C. (2000) Trophic cascades in benthic marine ecosystems: lessons for fisheries and protectedarea management. Environmental Conservation 27(2): 179-200.

Pipitone, C., Badalamenti, F., D'Anna, G. \& Patti, B. (1996) Divieto di pesca a strascio nel Golfo di Castellamare (Sicilia Nord-occidentale): alcune considerazione. Biologia Marina Mediterranea 3(1): 200-204.

Planes, S.E., Macpherson, F., Biagi, A., García Rubies, A., Harmelin, M., Harmelin-Vivien, J., Jouvenel, L., Tunesi, L., Vigliola, L. \& Galzin, R. (1999) Ecological and biological implications of spatio-temporal variability in growth of juvenile sparid fishes from the Mediterranean littoral. Fournal of the Marine Biological Association of the UK 79: 137-43.

Planes, S., Galzin, R., García Rubies, A., Goñi, R., Harmelin, J.-G., Le Diréach, L., Lenfant, P. \& Quetglas, A. (2000) Effects of marine protected areas on recruitment processes with special reference to Mediterranean littoral ecosystems. Environmental Conservation 27(2): 126-43.

Pollock, D.E. (1991a) Population regulation and stock-recruitment relationship in some crayfish and lobster populations. In: Crustacean Egg Production. Crustacean Issues, ed. A. Wenner \& A. Kuris, pp. 247-66. Rotterdam: Balkema.

Pollock, D.E. (1991b) Spiny lobster at Tristan da Cunha, South Africa: inter island variation in growth and population structure. South African Fournal of Marine Science 10: 1-12.

Pollock, D.E. (1993) Recruitment overfishing and resilience in spiny lobster populations. ICES Journal of Marine Science 50: 9-14.

Pollock, D.E. (1995) Changes in maturation ages and sizes in crustacean and fish populations. South African Journal of Marine Science 15: 99-103.

Pollock, D.E. (1997) Egg production and life-history strategies in some clawed and spiny lobster populations. Bulletin of Marine Science 61(1): 97-109.

Pollock, D.E. \& Goosen, P.C. (1991) Reproductive dynamics of the two Fasus species in the south Atlantic region. South African Fournal of Marine Science 10: 141-7.

Polovina, J.J. (1989) Density dependence in spiny lobster, Panulirus marginatus, in the Northwestern Hawaiian Islands. Canadian Fournal of Fisheries and Aquatic Sciences 46: 660-5.

Rakitin, A. \& Kramer, D.L. (1996) Effect of a marine reserve on the distribution of coral reef fishes in Barbados. Marine Ecology Progress Series 131: 97-113.

Ramos, A.A., Bayle, J.T. \& Sánchez Lizaso, J.L. (1992) Impact biologique et économique de la Reserve Marine de Tabarca (Alicante, Sud Est de l'Espagne). In: Impact Économique des Espaces Côtiers Protégés, ed. J. Olivier, N. Gerardin \& A. Jeudy De Grissac, pp. 59-66. France: Secrétariat du MEDPAN Publication.

Ramos Esplá, A.A. \& McNeil, S. (1994) The status of marine conservation in Spain. Ocean and Coastal Management 24: 125-38.

Rauck, G. \& Zijlstra, J.J. (1978) On the nursery aspects of the Wadden Sea for some commercial fish species and possible longterm changes. Rapport et Proces-Verbaux Réunions du Conseil International pour l'Exploration de la Mer 172: 266-75.
Reñones, O., Goñi, R., Pozo, M., Deudero, S. \& Moranta, J. (1999) Effects of protection on the demographic structure and abundance of Epinephelus marginatus (Lowe, 1834). Evidence from Cabrera Archipelago National Park (West-central Mediterranean). Marine Life 9(1-2).

Rijnsdorp, A.D. (1991) Changes in fecundity of female North Sea plaice (Pleuronectes platessa L.) between three periods since 1990. ICES Fournal of Marine Science 48: 253-80.

Rijnsdorp, A.D. (1993) Fisheries as a large-scale experiment in lifehistory evolution: disentangling phenotypic and genetic effects in changes in maturation and reproduction of North Sea plaice Pleuronectes platessa L. Oecologia 96: 391-401.

Rijnsdorp, A.D. \& van Beek, F.A. (1991) Changes in growth of North Sea plaice (Pleuronectes platessa L.) and sole (Solea solea L.). Netherlands Fournal of Sea Research 27: 441-57.

Rijnsdorp, A.D. \& van Leeuwen, P.I. (1992) Density-dependent and independent changes in somatic growth of female North Sea plaice Pleuronectes platessa between 1930 and 1984 as revealed by backcalculation of otoliths. Marine Ecology Progress Series 88: 19-32.

Rijnsdorp, A.D. \& van Leeuwen, P.I. (1996) Changes in growth of North Sea plaice since 1950 in relation to density, eutrophication, beam-trawl effort, and temperature. ICES fournal of Marine Science 55: 1199-213.

Rijnsdorp, A.D., Daan, F.A., van Beek, F.A. \& Heessen, H.J.L. (1991) Reproductive variability in North Sea plaice, sole and cod. Fournal du Conseil International pour l'Exploration de la Mer 47: 352-75.

Roberts, C.M. \& Polunin, N.V.C. (1991) Are marine reserves effective in management of coral reef fisheries? Reviems in Fish Biology and Fisheries 1: 65-91.

Roberts, C.M. \& Polunin, N.V.C. (1993) Effects of marine reserve protection on Northern Red Sea fish populations. Proceedings of the 7th International Coral Reef Symposium 2: 979-87.

Roberts, T.W. (1986) Abundance and distribution of pink shrimp in and around the Tortuga Sanctuary, 1981-1983. North American Fournal of Fisheries Management 6: 311-27.

Ross, R.M. (1990) The evolution of sex-change mechanisms in fishes. Environmental Biology 29: 81-93.

Rowley, R.J. (1994) Case studies and reviews. Marine reserves in fisheries management. Aquatic Conservation: Marine and Freshmater Ecosystems 4: 233-54.

Russ, G.R. \& Alcala, A.C. (1996) Do marine reserves export adult fish biomass? Evidence from Apo Island, Central Philippines. Marine Ecology Progress Series 132: 1-9.

Saborido-Rey, F. \& Junquera, S. (1998) Histological assessment of variations in sexual maturity of cod (Gadus morhua L.) at the Flemish Cap (north-west Atlantic). ICES Fournal of Marine Science 55: 515-21.

Sala, E., Boudouresque, C.F. \& Harmelin-Vivien, M.L. (1998) Fishing, trophic cascades, and the structure of algal assemblages: evaluation of an old but untested paradigm. Oikos 82: 425-39.

Shapiro, D.Y. (1981) Size, maturation and the social control of sex reversal in the coral reef fish Anthias squamipinnis. Fournal of Zoology 193: 105-28.

Shepherd, S.A (1990) Studies on southern Australian abalone (Haliotis). XII. Long term recruitment and mortality dynamics of an unfished population. Australian Journal of Marine and Freshmater Research 41: 475-92.

Shepherd, S.A. \& Brown, L.D. (1993) What is an abalone stock: implications for the role of refugia in conservation. Canadian Journal of Fisheries and Aquatic Sciences 50: 2001-2009. 
Shorthouse, B. (1990) The Great Barrier Reef Marine Park: how does it work for fishermen? Australian Fisheries 49: 16-17.

Sluka, R., Chiappone, M., Sullivan, K.M. \& Wrigth, R. (1997) The benefits of a marine fishery reserve for Nassau Grouper Epinephelus striatus in the Central Bahamas. Proceedings of the 8th International Coral Reef Symposium 2: 1961-4.

Stamps, J.A., Buechner, M. \& Krishnan, V.V. (1987) The effects of edge permeability and habitat geometry on emigration from patches of habitat. American Naturalist 129(4): 533-52.

Stearns, S.C. \& Crandall, R.E. (1984) Plasticity for age and size of sexual maturity: a life-historic response to unavoidable stress. In: Fish Reproductive Strategies and Tactics, ed. G.W. Potts \& R.J. Wooton, pp. 13-30. NY, USA: Academic Press.

Tegner, M.J. \& Dayton, P.K. (1976) Sea urchin recruitment patterns and implications for commercial fishing. Science 196: 324-6.

Trippel, E.A. (1995) Age at maturity as a stress indicator in fisheries. BioScience 45: 759-71.

Trippel, E.A., Kjesbu, O.S. \& Solemdal, P. (1997) Effects of adults age and size structure on reproductive output in marine fishes. In: Early Life History and Recruitment in Fish Populations, ed. E.C. Chambers \& E.A. Trippel, pp: 31-62. London, UK: Chapman \& Hall.

Tupper, M. \& Juanes, F. (1999) Effects of a marine reserve on the recruitment of grunts (Pisces: Haemulidae) at Barbados, West Indies. Environmental Biology of Fishes 55: 53-63.

Valiela, I. (1984) Marine Ecological Processes. New York, USA: Springer-Verlag Inc: 686 pp.

Van Rooij, J.M., Kok, J.P. \& Videler, J.J. (1996) Local variability in population structure and density of the protogynous reef herbivore Sparisoma viride. Environmental Biology of Fishes 47: 65-80.
Victor, B.C. (1986) Larval settlement and juvenile mortality in a recruitment-limited coral reef fish population. Ecological Monographs 56: 145-60.

Wahle, R.A. \& Steneck, R.S. (1991) Recruitment habitats and nursery grounds of the American Lobster Homarus americanus: a demographic bottleneck? Marine Ecology Progress Series 69: 231-43.

Warner, R.R. (1982) Mating systems, sex change and sexual demography in the rainbow wrasse, Thalassoma lucasanum. Copeia 3: 653-61.

Warner, R.R. \& Chesson, P.L. (1985) Coexistence mediated by recruitment fluctuations: a field guide to the storage effect. American Naturalist 125: 769-87.

Warner, R.R. \& Hoffman, S.G. (1980a) Population density and the economics of territorial defense in a coral reef fish. Ecology 61(4): 772-80.

Warner, R.R. \& Hoffman, S.G. (1980b) Local population size as a determinant of mating system and sexual composition in two tropical marine fishes (Thalassoma spp.) Evolution 34: 508-18.

Wootton, R.J. (1990) Ecology of Teleost Fishes. New York: Chapman and Hall: 404 pp.

Yamasaki, A. \& Kuwahara, A. (1990) Preserved area to effect recovery of overfished Zuwai crab stocks off Kyoto Prefecture. In: Proceedings of the International Symposium on King and Tanner Crabs, pp. 575-85. Alaska Sea Grant College Program, University of Alaska.

Zhao, B. \& McGovern, J.C. (1997) Temporal variation in sexual maturity and gear-specific sex ratio of the vermilion snapper, Rhomboplites aurorubens, in the South Atlantic Bight. Fishery Bulletin 95: 837-48. 